\title{
Human skin penetration of a copper tripeptide in vitro as a function of skin layer
}

\author{
Jurij J. Hostynek · Frank Dreher · Howard I. Maibach
}

Received: 24 September 2009/Accepted: 16 July 2010/Published online: 20 August 2010

(C) The Author(s) 2010. This article is published with open access at Springerlink.com

\begin{abstract}
Objective and design Skin retention and penetration by copper applied as glycyl-L-histidyl-L-lysine cuprate diacetate was evaluated in vitro in order to assess its potential for its transdermal delivery as an anti-inflammatory agent.

Materials and methods Flow-through diffusion cells with $1 \mathrm{~cm}^{2}$ exposure area were used under infinite dose conditions. $0.68 \%$ aq. copper tripeptide as permeant was applied on isolated stratum corneum, heat-separated epidermis and dermatomed skin and receptor fluid collected over $48 \mathrm{~h}$ in $4 \mathrm{~h}$ intervals using inductively coupled plasma mass spectrometry to analyze for copper in tissues and receptor fluid.

Results The permeability coefficient of the compound through dermatomed skin was $2.43 \pm 0.51 \times 10^{-4} \mathrm{~cm} / \mathrm{h}$; $136.2 \pm 17.5 \mu \mathrm{g} / \mathrm{cm}^{2}$ copper permeated $1 \mathrm{~cm}^{2}$ of that tissue over $48 \mathrm{~h}$, while $97 \pm 6.6 \mu \mathrm{g} / \mathrm{cm}^{2}$ were retained as depot.

Conclusions Copper as tripeptide was delivered in potentially therapeutically effective amounts for inflammatory disease.
\end{abstract}

Keywords Absorption - Arthritis - Bioavailability · Copper complex $\cdot$ Depot $\cdot$ Inflammation

Responsible Editor: Michael Parnham.

J. J. Hostynek ( $₫)$ · F. Dreher · H. I. Maibach

Department of Dermatology, UCSF School of Medicine,

San Francisco, CA, USA

e-mail: jurij.hostynek65@gmail.com

J. J. Hostynek · F. Dreher · H. I. Maibach

Department of Dermatology, University of California,

Surge 110, San Francisco, CA 94143-0989, USA

\section{Introduction}

Acute and chronic inflammation are characterized by changes in the metabolism of copper and by a pronounced responsiveness to therapy with copper compounds $[1,2]$. The copper content and ceruloplasmin activity of serum are significantly elevated above normal values in inflammatory diseases in man and laboratory animals, and copper in widely different chemical forms is used as therapeutic agent in therapy for chronic and acute inflammation [2]. The rise in total serum copper measured in inflammation is held to represent the natural anti-inflammatory (AI) response of the organism itself. The responsiveness of inflammatory disorders to copper supplementation noted suggests that the control exerted by endogenous copper on inflammation is susceptible to enhancement by exogenous sources. When copper complexes were administered subcutaneously, the reduction in inflammation was proportional to total amount of copper injected [3].

The present research seeks a viable transdermal alternative to what so far has been a therapy for inflammatory disorders relying on intra-articular or intramuscular injection of drugs which can cause patient discomfort and untoward side effects. Data on human skin penetration by copper compounds is rare. Pirot et al. [4] determined the Skin permeability $(\mathrm{Kp})$ for copper sulfate and chloride at 3.2 and $2.3 \times 10^{-6} \mathrm{~cm} / \mathrm{h}$, respectively, for the pyrrolidone carboxylate at $5.7 \times 10^{-5} \mathrm{~cm} / \mathrm{h}$. Using a model membrane made of stratum corneum lipids, Mazurowska suggested that copper peptides, and GHK-Cu in particular, might permeate skin [5-7]. Experiments using skin models generally underestimate absorption since the composition of model membranes does not reflect the stratum corneum, a heterogeneous, multicomponent membrane [8-10]. Orth [11] and Finkey [12] measured uptake of copper into 
superficial facial skin strata in vivo when applying glycylL-histidyl-L-lysine copper cuprate, diacetate (GHK-Cu). However, to date, bioavailability of copper was not studied quantitatively using human skin ex vivo. Therefore, evidence that copper does penetrate the skin in any form is so far based on its observed effects only. Anti-inflammatory (AI) activity by topical application of copper complexes was shown in animals by Brown [1], and in man by Sorenson [2], and has been extensively reviewed by Milanino [13].

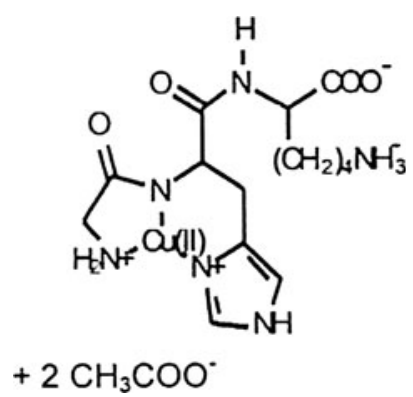

Chemical: Glycyl-L-histidyl-L-lysine copper cuprate, diacetate GHK$\mathrm{Cu}(\mathrm{Ac})_{2}$, Formula: $\mathrm{C}_{18} \mathrm{H}_{29} \mathrm{CuN}_{6} \mathrm{O}_{8}$

Criteria for optimal diffusivity of cupriphores are hard to define due to the complexity of equilibria that zwitterions are subject to in the variable systemic environments they encounter upon diffusion. Earlier investigations, however, help in the design of complexes of adequate pharmacological activity. Those include:

- Copper derivatives of well-known antiarthritic drugs, including steroidal and nonsteroidal AI agents. The copper complexes of those drugs have been found to be active or more effective AI agents than the parent drugs [14].

- The AI effect of copper is non-specific with respect to inflammatory pathologies and is enhanced by exogenous sources [13].

- AI activity of exogenous copper sources is independent of ligand [15]. On topical administration, copper complexes are subject to dynamic ligand exchange in the process of diffusion through skin [16]. Thereby, copper oxidation state can change from monovalent to divalent to the elemental state, and the original complex administered topically is likely to differ from the complex which subsequently forms with endogenous amino acids to act as an AI agent [17].

The function of copper ligands thus is to promote skin penetration only, and this study evaluates skin penetration of a nature-identical copper complex [18]. If therapeutically significant, that is, if transdermal AI therapy can be achieved, it may present an alternative to current approaches involving intra-articular or intramuscular injection, which can cause patient discomfort, particularly in arthritic patients where long term therapy is employed.

\section{Materials and methods}

\section{Materials}

The permeant was GHK-Cu received from the ProCyte Corp. (Kirkland, WA). It was not analyzed for stoichiometric purity since, in several studies, copper complexes in a physiological environment were subject to de-complexation and rearrangement, depending on $\mathrm{pH}$ and complex stability constants [11, 19-21]. Those investigations indicated the presence of multiple species for GHK-Cu (e.g., tri-and hexa-peptide) in solutions, together with copper-free oligopeptide. Copper as a transition metal of variable oxidation states has the ability to form complexes with different geometries and stability. Here, the copper tripeptide is summarily referred to as GHK-Cu. Concentrations are reported in terms of copper per $\mathrm{ml}$ of solution.

Experimental design

Copper penetration was studied using split thickness skin, isolated stratum corneum and entire epidermis.

Tissue preparation

Human cadaver skin was obtained from the Northern California Transplant Bank (San Rafael, CA) and stored in a freezer $\left(-20^{\circ} \mathrm{C}\right)$ until use. All experiments were performed within 2 months after freezing. All subjects were Caucasian, aged 21-53 years, and both genders were represented.

Split thickness skin (entire epidermis with a portion of the dermis) was obtained by use of a dermatome targeted to $500 \mu \mathrm{m}$ and stored $\left(-20^{\circ} \mathrm{C}\right)$ until use.

Entire epidermis, (isolated. epidermis incl. stratum corneum), was obtained by heat separation $\left(60^{\circ} \mathrm{C}\right)$ and stored $\left(-20^{\circ} \mathrm{C}\right)$ until use.

Isolated stratum corneum was obtained from isolated epidermis which was placed on Whatman paper soaked in a $0.05 \% \mathrm{w} / \mathrm{w}$ trypsin Type III (from bovine pancrease, Sigma Chemical, St. Louis, USA) solution in $0.15 \mathrm{M}$ phosphate buffered saline (PBS, pH 7.4, Sigma) for $2 \mathrm{~h}$ at $37^{\circ} \mathrm{C}$. Remaining trypsin activity was blocked by submerging the stratum corneum sheet in $0.05 \% \mathrm{w} / \mathrm{w}$ trypsin inhibitor Typed II (from soybean, Sigma Chemicals, St. Louis, USA), then the stratum corneum sheet was washed twice in purified water, dried and stored above silica gel at room temperature. 
Separation of epidermis (incl. stratum corneum) from dermis following split thickness skin diffusion experiment C (sep. epidermis): recovered split thickness skin was placed on polyethylene film, covered with polyethylene film and placed under an aluminum block heated to $65^{\circ} \mathrm{C}$ for $90 \mathrm{~s}$, allowing separated epidermis to be lifted from the dermis.

\section{Diffusion experiment}

Replicates were run on tissue from the same donor. Glass low-volume flow cells with $1 \mathrm{~cm}^{2}$ exposure area were kept at $37^{\circ} \mathrm{C}$. Receptor fluid was collected over $48 \mathrm{~h}$ in $4 \mathrm{~h}$ intervals. Cells were mounted in the wells of an aluminum cell holder (Stratacor, Richmond, CA), whose internal channels were perfused with water at $37^{\circ} \mathrm{C}$ from a circulating water bath, and holders were mounted on a fraction collector. Water containing $1 \mathrm{ml} / \mathrm{l}$ of gentamycin sulfate solution $(100 \mathrm{mg} / \mathrm{ml})$ was pumped through the cells at approximately $2 \mathrm{ml} / \mathrm{h}$. Tissues were cut into circles with a biopsy punch $\left(1 \mathrm{~cm}^{2}\right)$, mounted on the diffusion cells and the donor chambers clamped in place.

To test for tissue integrity, prior to the experiment with tissue discs clasped in place, the peristaltic pump was run at $10 \mathrm{rpm}$, generating back pressure in the receptor cells (five times the normal pressure) for $2 \mathrm{~h}$ to check for leakers, which were eliminated.

About $1 \mathrm{ml}$ of test solution was placed in the donor chambers, closed with ground glass stoppers and sealed with Parafilm to prevent donor solution evaporation.

At completion, the content of donor cells were collected with a pipette, the skin surface washed $(3 \times 2 \mathrm{ml})$ with distilled water and the rinses saved in LSC vials with polyethylene capliners (Perkin-Elmer, Shelton, CT).

\section{Analytical methodology}

For original copper levels, portions of isolated stratum corneum, isolated epidermis, as well as split thickness dermis were analyzed to determine the increment retained there during diffusion. Following diffusion experiment C, split thickness skin was also separated into epidermis and dermis (entire separated epidermis and separated dermis) for analysis of tissue depot formation in the experiment.

Experimental details and results are reported in terms of copper, analyzed by inductively coupled plasma mass spectrometry (ICP-MS).

Analyses were performed by DuPont Analytical Solutions, Wilmington, DE. There, samples were prepared by diluting 1:10 (volume/volume), using $2 \% \mathrm{HNO}_{3}$ immediately prior to analysis by ICP-MS. The ICP-MS equipment used was an Agilent 7500c, operated under helium collision gas mode. The instrumental detection limit was
$<100 \mathrm{pg} / \mathrm{ml}$ copper. Standard solutions were prepared by diluting a $1,000-\mu \mathrm{g} / \mathrm{ml} \mathrm{Cu}$ stock solution with $2 \% \mathrm{HNO}_{3}$. Two separate (low concentration and high concentration) six-point external calibration curves $\left(r^{2}>0.999\right)$ were used for quantitation of both copper isotopes (63 and 65 $\mathrm{Cu}$ ) with $89 \mathrm{Y}$ used as an internal standard. The low concentration calibration curve was constructed from 1, 2, 5, 10 , and $20 \mathrm{ng} / \mathrm{ml} \mathrm{Cu}$ standards and the high concentration calibration curve was from 20,100,1,000, 5,000, and $10,000 \mathrm{ng} / \mathrm{ml} \mathrm{Cu}$ standards. The instrument was calibrated using the five standards above, and the samples bracketed between the standards without extrapolation either below the calibration curve or above it.

\section{Data analysis}

$\mathrm{Kp}(\mathrm{cm} / \mathrm{h})$ was calculated from steady-state flux Jss $\left(\mu \mathrm{g} / \mathrm{cm}^{2} / \mathrm{h}\right)$ of copper. Tissue copper levels reported from diffusion experiments were corrected for endogenous levels determined prior to the experiments.

Standard deviations (SD) were calculated by the XL program.

\section{Results}

Skin permeability coefficients $(\mathrm{Kps})$ for the copper tripeptide ranged from $3 \times 10^{-7} \mathrm{~cm} / \mathrm{h}$ through isolated epidermis (Table 1, Exp. B) to $5.54 \times 10^{-3} \mathrm{~cm} / \mathrm{h}$ through isolated stratum corneum (Table 1, Exp. A).

Lag times measured from $2 \mathrm{~h}$ on isolated stratum corneum and spilt thickness skin (Table 1, Exp. A, C), to $7 \mathrm{~h}$ on isolated epidermis (Table 1, Exp. B).

Copper collected in the receptor fluid in $48 \mathrm{~h}$ ranged from $0.60 \pm 0.21 \mu \mathrm{g} / \mathrm{cm}^{2}$ or $0.006 \pm 0.001 \%$ of the dose through isolated epidermis (Exp. B; Table 2), to $136.2 \pm$ $17.5 \mu \mathrm{g} / \mathrm{cm}^{2}$ or $2.0 \pm 0.31 \%$ through split thickness skin (Exp. C, Table 2).

Amounts of membrane retention in stratum corneum tissue were $290 \pm 69 \mu \mathrm{g} / \mathrm{cm}^{2}$, a 438 -fold increase over baseline levels (Tables 2, 3, Exp. A), and a total $96.9 \mu \mathrm{g} / \mathrm{cm}^{2}$ in the complete dermatomed skin (Table 2, Exp. C) based on analysis of the separated strata after diffusion through split thickness skin.

\section{Discussion}

This study evaluated absorption and skin retention of a copper tripeptide on separate skin compartments: the stratum corneum, epidermis and split thickness skin.

The amount of copper deposited from the tripeptide in the stratum corneum as well as in the entire epidermis and 
Table 1 Copper skin penetration as function of skin strata from aq. GHK-Cu solution

\begin{tabular}{llccc}
\hline Exp. & Skin strata & $\mathrm{Kp} \times 10^{4}(\mathrm{~cm} / \mathrm{h}) \pm \mathrm{SD}$ & Flux $\left(\mu \mathrm{g} / \mathrm{cm}^{2} / \mathrm{h}\right) \pm \mathrm{SD}$ & $\mathrm{Lag}$ time $(\mathrm{h})$ \\
\hline A & Isolated stratum corneum $(n=3)$ & $55.9 \pm 13.2$ & $38 \pm 9$ & 2 \\
B & Isolated epidermis $(n=3)$ & $0.003 \pm 0.0006$ & $0.002 \pm 0.0004$ & 7 \\
$\mathrm{C}$ & Dermatomed skin $(n=8)$ & $2.5 \pm 0.51$ & $1.7 \pm .35$ & 2 \\
\hline
\end{tabular}

Table 2 Human skin penetration and retention of copper in function of skin strata after $48 \mathrm{~h}\left(\mu \mathrm{g} / \mathrm{cm}^{2}\right.$; percent of applied dose)

\begin{tabular}{|c|c|c|c|c|c|c|c|}
\hline Exp. & Skin strata & $\begin{array}{l}\text { Donor } \\
\text { recovered }\end{array}$ & Stratum corneum & Total epidermis & Dermis & Receptor fluid & $\begin{array}{l}\text { Total } \\
\text { recovered }\end{array}$ \\
\hline A & $\begin{array}{l}\text { Isolated stratum } \\
\quad \text { corneum }(n=3)\end{array}$ & $(79 \pm 13)$ & $\begin{array}{l}290.3 \pm 69 \\
\quad(4.0 \pm 0.15)\end{array}$ & NA & NA & $\begin{array}{l}2,110 \pm 589 \\
\quad(19.85 \pm 3.9)\end{array}$ & $(98 \pm 27)$ \\
\hline B & $\begin{array}{l}\text { Isolated epidermis } \\
\quad(n=3)\end{array}$ & $(94 \pm 12)$ & ND & $\begin{array}{l}59.7 \pm 13.1 \\
\quad(1.0 \pm 0.3)\end{array}$ & NA & $\begin{array}{l}0.60 \pm 0.21 \\
\quad(0.006 \pm 0.001)\end{array}$ & $(95 \pm 12)$ \\
\hline $\mathrm{C}$ & $\begin{array}{l}\text { Split thickness } \\
\quad(n=8)\end{array}$ & $91 \pm 14$ & ND & $\begin{array}{l}1.0^{\mathrm{a}} \pm 0.4 \\
\quad(66.0 \pm 6,6)\end{array}$ & $\begin{array}{l}0.09 \pm 0.01 \\
\quad\left(30.9^{\mathrm{a}} \pm 6.8\right)\end{array}$ & $\begin{array}{l}136.2 \pm 17.5 \\
\quad(2.0 \pm 0.31)\end{array}$ & $(94 \pm 7)$ \\
\hline
\end{tabular}

$N A$ not applicable; $N D$ not determined

${ }^{a}$ Separated following split thickness diffusion

Table 3 Copper reservoir in skin layers versus original levels from $0.68 \%$ aq. GHK-Cu at $48 \mathrm{~h}$

\begin{tabular}{llcr}
\hline Skin compartment & $\mathrm{Cu}$ at $0 \mathrm{~h}\left(\mu \mathrm{g} / \mathrm{cm}^{2}\right)$ & $\mathrm{Cu}$ at $48 \mathrm{~h}\left(\mu \mathrm{g} / \mathrm{cm}^{2}\right)$ & Increase vs. $0 \mathrm{~h}$ \\
\hline Isolated SC (Exp. A) & $0.68 \pm 0.28 ; n=3$ & $290 \pm 69 ; n=3$ & $438 \times$ \\
Isolated Epi (Exp. B) & $0.37 \pm 0.17 ; n=3$ & $61.1 \pm 7.0 ; n=3$ & $165 \times$ \\
Dermatomed skin (Exp. C) $_{\text {Separated epidermis }^{\mathrm{a}}}$ & $1.72 \pm 0.47 ; n=8$ & $53 \pm 8.1 ; n=8$ & $31 \times$ \\
Separated dermis $^{\mathrm{b}}$ & $0.37 \pm 0.7 ; n=8$ & $66.7 \pm 7.89 ; n=8$ & $180 \times$ \\
\hline
\end{tabular}

a Separated following split thickness diffusion; total epidermis

b Dermis separated from split thickness skin following the diffusion experiment

dermis appears remarkable. For instance, an about 400-fold increase over baseline was found in the stratum corneum alone. Such high tissue retention of copper may be attributed to intradermal decomplexation and re-binding to various endogenous amino acids with higher nucleophilic donor capacity than the original ligand.

Whether or not skin levels retained in the stratum corneum and epidermis/dermis in the diffusion process of drugs should be included in the overall estimation of absorbed material, i.e., assessing whether permeant retained in skin tissues eventually will become available systemically, is an issue of ongoing discussions. Reservoir formation in the course of in vitro studies, in particular, has been addressed [22]. Retained drug may be lost to natural desquamation, limiting its eventual systemic availability, to be sure. On closer analysis, however, it was also found that the fraction of chemical that sloughs off versus the part that becomes systemically available depends on the ratio of lag time to the turnover time for the stratum corneum [23]. Accordingly, at least $80 \%$ of the amount in the stratum corneum will become available if the lag time for penetration through the stratum corneum is less than about $16 \mathrm{~h}$, which corresponds to $5 \%$ of the stratum corneum turnover time of typically 14 days. Consequently, based on our results where lag times ranged from 2 to $7 \mathrm{~h}$, the copper retained in the stratum corneum may become largely systemically available. As a result of the experiment with dermatomed skin, by topical application of $\mathrm{GHK}-\mathrm{Cu}$ under the present conditions $200-250 \mu \mathrm{g} / \mathrm{cm}^{2}$ copper would become systemically available. Since the experiment was conducted ex vivo, it is possible that even larger amounts will be retained in the deeper dermal tissue there, followed by penetration in vivo.

The permeation rate of $\mathrm{GHK}-\mathrm{Cu}$ through stratum corneum seems high, the highest of all three skin strata studied. It seems consistent with a model of porous transport, as appendageal penetration is considered to be one, if not the predominant pathway for the diffusion of multipolar ions [24-26]. In addition, the high penetration level through stratum corneum alone can be explained by the fact that there was no tissue retention from underlying skin that may have limited penetration. 
The high hydrophilicity of the copper tripeptide (pseudo $\log P_{\text {ow }}=-4.5$, quotient sat. n-octanol/sat. aqueous solution), ${ }^{1}$ is reconcilable with shunt penetration typical for highly hydrophilic solutes such as salts. Significant penetration through appendages can occur within minutes following exposure, in contrast to non-appendageal pathways [27-30].

However, the Kps of GHK-Cu through epidermis and dermatomed skin were lower at about one order of magnitude. Restriction of the pore area may cause the discrepancy in the diffusion constant. This suggests, in fact, that the diffusion pathway for copper penetration is restricted as compared to stratum corneum alone.

Skin retention and permeation by metal complexes is not often investigated, and our observations on the subject of a copper tripeptide merit more detailed discussion.

Copper is an essential trace element, critical for a variety of biological processes; for hemoglobin synthesis, enzyme activation, (i.e., superoxide dismutase), or more generally as a key component of mitochondrial, cytoplasmic and nuclear enzyme systems [31].

It is a key factor in the production of collagen and elastin $[11,12,18]$, and the AI activity of numerous copper complexes is well documented [13, 32]. Such activity was greater than either treatment with inorganic copper salts or the complexing agents alone: while many among the parent compounds or ligands were inactive in test models of inflammation even at larger screening doses, in coordination with copper they were active. The compounds thus investigated include copper complexes of well-known antiarthritic drugs, including steroidal and nonsteroidal anti-inflammatory drugs: niflumic acid, D-penicillamine, hydrocortisone, dexamethasone, dimethylsulfoxide, clopirac, ketoprofen, (+)-naproxen, indomethacin, mefenamic acid, diclofenac, ibuprofen among a number of others. The copper complexes of those drugs have been found to be more effective anti-inflammatory agents than the parent drugs [33, 34].

Acute or chronic inflammation induces a net increase of total copper in blood, synovial fluid and inflamed areas, mobilized from endogenous stores [13]. Chronic inflammation may lead to depletion of copper stores, implying the need for exogenous copper supply in order to effectively cope with the inflammatory pathologies. While copper complexes are commonly administered by injection, the AI activity of subcutaneous administration of copper complexes in animals was also shown to be proportional to total amount of copper injected [34].

The present study indicates that topical administration of copper in form of the tripeptide may offer an effective

\footnotetext{
${ }^{1}$ RCC, 2002. Determination of the partition coefficient (n-octanol/ water) of copper tripeptide-1 (PC 1044). RCC Ltd, Environmental Chemistry \& Parmaceutical Division; CH-4452 Ittingen/Switzerland.
}

alternative to injection. Since a realistic dimension for topical application of GHK-Cu as patch may cover $10 \mathrm{~cm}^{2}$ of skin, based on our results $2.33 \mathrm{mg}$ of copper would become available over $48 \mathrm{~h}$. This may be compared to a subcutaneous injection of $300 \mathrm{mg} / \mathrm{kg}$ of copper aspirinate in rats without adverse effects, while it proved effective in treating experimental subplantar edema even at a dose of $10 \mathrm{mg} / \mathrm{kg}$.

When administering copper to the organism, its toxicity should be addressed.

There is ample evidence that the copper ions released will be subject to the highly efficient homeostatic control in eukaryotic organisms that prevents its circulation at untoward levels. Levels of free ionic $\mathrm{Cu}$, a relatively toxic metal, are moderated to the minimum levels sufficient for physiologic needs, reported in the range of $10^{-11}$ to $10^{-19}$ mol estimated in plasma, by binding to ceruloplasmin and metallothionein $[35,36]$. The dynamic equilibrium between ceruloplasmin and metallothionein stored in liver tissue prevents toxic accumulation of free copper ion in mammals [37]. That hepatic reservoir is released slowly back into the blood as ceruloplasmin and copper metallothionein in response to inflammation due to injury or arthritis [38]. The average level of bound copper in human control plasma is $1.12 \mu \mathrm{g} / \mathrm{ml}$ [39]; in arthritic patients it is $1.40 \mu \mathrm{g} / \mathrm{ml}$ [40]. A therapeutically effective copper level in inflammation cannot be assessed in definite terms, however, because copper status induced in response to inflammatory diseases in humans varies depending on target organ [13].

In contrast to injection, in topical application the skin forms a natural barrier which controls drug release over an extended period, under approximately steady conditions over a period of days. Flux, and not elimination from the skin surface seems to be the limiting step, and repeated dosage may result only in a build-up on the surface, possibly without significantly affecting the kinetics.

Both historical and more recent investigative data illustrate the safe exposure to exogenous copper as metal, as its salts, or in complex form. Records on human exposure to copper and its benefits date back to prehistoric times [41, 42]. As an example, in current medical practice copper histidinate is administered intravenously to children suffering from Menke's disease (a.k.a. kinky hair syndrome), a genetically transmitted inability to absorb the metallo element. In the following, three examples for the efficacy of topical copper compounds are provided:

1. Based on the observation that topical applications of copper salicylate produced anti-inflammatory effects in humans volunteers, in certain countries (e.g., Australia), ethanolic $\mathrm{Cu}(\mathrm{II})$ salicylate-containing preparations (Alcusal) are available over the counter for 
human use to alleviate arthritic pain [43], an example of synergism between $\mathrm{Cu}$ (II) and an AI drug.

2. A chlorophyllin copper complex (CCC), derived from chlorophyll by replacing the chelated magnesium with copper, has anti-inflammatory and antimicrobial properties, as well as a marked stimulating effect on epithelial cell growth rates and cell regeneration. First established in tissue culture studies, these findings were confirmed clinically through wound healing and deodorizing characteristics observed in animals and humans [44]. Administered orally, CCC is classified as a safe and effective internal deodorant by the US FDA [45].

3. In order to document the tolerability of metallic copper which must be oxidized in contact with the skin in order to penetrate, Gorter examined absorption and tolerance of metallic copper-containing ointments on human volunteers over a period of several weeks. Copper analysis in serum showed that levels had increased significantly above control levels, without overt untoward effects, either in the skin or systemically, following application of ointments containing up to $20 \%$ of the metal in its elemental form [46]. It is well established that the $\mathrm{Kp}$ of organic chemicals is determined by their lipophilicity and size [47]. This is also likely to apply to (transition) metals complexed with ligands subject to changes in $\mathrm{pH}$ and other parameters in the skin with depth [48], which determine ionization as well as availability of ligands and lipophilicity. Copper, a transition metal of variable oxidation state, has the ability to form complexes with different geometries and stability.

Similar to most transition metals, the mechanism by which copper complexes permeate skin is little understood. While copper distribution in the tissues analyzed resulted in remarkably high stratum corneum retention, through that barrier it also reached the highest values in the receptor fluid. Under present study conditions, significant passive transport of the copper species across separate skin strata of differing barrier properties seems to indicate the various potential routes of passage from the surface of the skin into the subepidermal or dermal tissue: the appendageal, the inter- and the intra-cellular pathways. Further, an additional factor appeared to determine the results obtained: intrinsic complex rearrangement in the various skin compartments leading to retention and diffusion of copper ion as a function of ligand. An undetermined part of copper might transit through the skin as the undissociated original tripeptide, and another might diffuse bound to endogenous amino acids of higher complex stability constants such as the histidinate [21], the predominant copper complex in plasma, with cystinate as the secondary ligand.
Studies with labeled ligands (i.e., radio-labeled) may help with further understanding the complex skin penetration behavior of copper complexes. In the present study, only diffusion followed by copper analysis on isolated or separated tissue strata allowed a measure of insight.

\section{Conclusions}

Quantitative assessment of skin penetration and specifying the actual penetration mechanism for a copper peptide is difficult due to possible ligand exchanges during diffusion. The results described here, however, show that a topical organic copper complex such as $\mathrm{GHK}-\mathrm{Cu}$ may be an alternative to copper delivery by injection, also potentially providing a skin reservoir likely to become available over time. This effect warrants further development towards transdermal delivery of the AI agent, especially when considering GHK, a nature-identical carrier tripeptide [18]. Several laboratories in the past had demonstrated local and systemic AI activity of copper compounds by oral, ip, iv, and particularly subcutaneous administration. Having shown permeation of the skin barrier by $\mathrm{GHK}-\mathrm{Cu}$ in a therapeutically effective dose here, application of the principal to transdermal dosing now may become a realistic alternative to current, traditional routes and agents, however. Taking our results a step further, controlled release of copper for AI therapy using patch technology could be optimized with well-designed formulations. The fact that a deficit in that essential element may be significantly corrected by choosing appropriate cupriphores is a significant outcome of our endeavours towards alleviating rheumatoid arthritis and similar musculoskeletal conditions often afflicting the general population.

Acknowledgments We express our appreciation for the guidance received from the late Roberto Milanino, MD, of the University of Verona, who brought insight into the biological relevance of our research and to whose memory we dedicate this manuscript. We thank Len Patt of the ProCyte Corporation (Redmond, WA) for making a complimentary sample of the copper tripeptide available for our investigation. We thank Larry Ryan, DuPont Analytical Solutions (Wilmington, DE) for supervising inductively coupled plasma mass spectroscopy analyses, and Jeannette Woodward for their execution.

Open Access This article is distributed under the terms of the Creative Commons Attribution Noncommercial License which permits any noncommercial use, distribution, and reproduction in any medium, provided the original author(s) and source are credited.

\section{References}

1. Brown DH, Smith WE, Teape JW, Lewis AJ. Anti-inflammatory effects of some copper complexes. J Med Chem. 1980;23: 729-34. 
2. Sorenson JRJ. Copper chelates as possible active forms of the antiarthritic agents. J Med Chem. 1979;19:135-48.

3. Jackson GE, Mkhonta-Gama L, Voye A, Kelly M. Design of copper-based anti-inflammatory drugs. J Inorg Biochem. 2000;79:147-52.

4. Pirot F, Millet J, Kalia YN, Humbert P. In vitro study of percutaneous absorption, cutaneous bioavailability and bioequivalence of zinc and copper from five topical formulations. Skin Pharmacol. 1996;9:259-69.

5. Mazurowska L, Nowak-Buciak K, Mojski M. ESI-MS method for in vitro investigation of skin penetration by copper-amino acid complexes: from an emulsion through a model membrane. Anal Bioanal Chem. 2007;38:1157-63.

6. Mazurowska L, Nowak-Buciak K, Mojski M. ESI-MS study of the mechanism of glycyl-L-histidyl-L-lysine-Cu(II) complex transport through model membranes of stratum corneum. Talanta. 2007;72:650-4.

7. Mazurowska L, Mojski M. Biological activities of selected peptides: skin penetration ability of copper complexes with peptides. J Cosmet Sci. 2008;59:59-69.

8. Hadgraft J, Rideout G. Development of model membranes for percutaneous absorption measurements. I. Isopropyl myristate. Int J Pharm. 1987;39:149-56.

9. Schaefer H, Redelmeier TE. Permeability properties of the stratum corneum. In: Skin Barrier. Principles of percutaneous absorption. New York: Karger; 1996. pp. 87-117.

10. Schaefer H, Lademann J. The role of follicular penetration-a differential view. Skin Pharmacol Appl Physiol. 2001;14(Suppl 1): 23-7.

11. Orth DS, Widjaja J, Ly L, Cao N, Shapiro WB. Stability of skin persistence of topical products. Cosmet Toiletries. 1998;113: 51-63.

12. Finkey M, Appa Y, Bhandarkar S. Copper peptide and skin. In: Elsner P, Maibach HI, editors. Cosmeceutical and active cosmetics. New York: Taylor and Francis; 2005. p. 550-64.

13. Milanino R, Buchner V. Copper: role of the endogenous and exogenous metal on the development and control of inflammatory processes. Rev Environ Health. 2006;21:153-215.

14. Sorenson JRJ, Berthon G. Copper potentiation of non-steroidal antiinflammatory drugs. In: Handbook of metal-ligand interactions in biological fluids, 1st edn. New York: Marcel Dekker, Inc.; 1995. pp. 1318-1356.

15. Chohan ZH, Iqbal MS, Iqbal HS, Scozzafava A, Supuran CT. Transition metal acetylsalycilates and their anti-inflammatory activity. J Enzyme Inhib Med Chem. 2002; 117:1787-89.

16. Williams DRJ, Furnival C, May PM. Computer analysis of low molecular weight copper complexes in biofluids. In: Sorenson JRJ, editor. Inflammatory diseases and copper. Clifton, NJ: Humana Press; 1982. p. 45-56.

17. Brown HD, Dunlop J, Smith WE, Teape J, Lewis AJ. Total serum copper and ceruloplasmin levels following administration of copper aspirinate to rats and guinea-pigs. Agents Actions. 1980;10:465-70.

18. Pickart L. The human tri-peptide GHK and tissue remodeling. J Biomater Sci Polymer Edn, vol. 19, no. 8. Leiden: Koninklijke Brill NV; 2008. pp. 969-988.

19. Freedman JH, Pickart L, Weinstein B, Mims WB, Peisach J. Structure of the Glycidyl-L-histidyl-L-lysine-Copper(II) complex in solution. Biochemistry. 1982;21:4540-4.

20. Conato C, Gavioli R, Guerrini R, Kozlowski H, Mlynarz P, Pasti C, Pulidori F, Remelli M. Copper complexes of glycyl-histidyllysine and two of its synthetic analogues: chemical behaviour and biological activity. Biochim Biophys Acta. 2001;1526:199-210.

21. Deschamps P, Kulkarni PP, Gautam-Basak M, Sarkar B. The saga of copper(II)-L-histidine. Coord Chem Rev. 2005;249: 895-909.
22. Yourick JJ, Koenig ML, Yourick DL, Bronaugh RI. Fate of chemicals in skin after dermal application: does the in vitro skin reservoir affect the estimate of systemic absorption? Toxicol Appl Pharmacol. 2004;195:309-20.

23. Reddy MB, Bunge AL. In: Bronaugh RL, Maibach HI, editors. Percutaneous absorption. 4th edn. New York: Marcel Dekker; 2005. pp. 165-176.

24. Tur E, Maibach HI, Guy RH. Percutaneous penetration of methyl nicotinate at three anatomical sites: evidence for an appendageal contribution to transport? Skin Pharmacol. 1991;4:230-4.

25. Potts RO, Guy RH, Francoeur ML. Routes of ionic permeability through mammalian skin. Solid State Ionics. 1992;53-56:165-9.

26. Mazzenga GC, Berner B, Jordan F. The transdermal delivery of zwitterionic drugs II: the flux of zwitterionic salts. J Contr Rel. 1992;20:163-70.

27. Sznitowska M, Berner B, Maibach HI. Percutaneous penetration of multipolar ions: evidence for porous transport. Int J Pharm. 1995;123:41-5.

28. Lademann J, Otberg N, Richter H, Jacobi U, Schaefer H, BlumePeytavi U. Folliculaere Penetration-Ein entscheidender Penetrationswegvon topisch applizierten Substanzen. Hautarzt. 2003;54:321-3.

29. Abramson HA, Gorin MH. The electrophoretic demonstration of the patent pores of the living human skin in relation to the charge of the skin. J Phys Chem. 1940;44:1094-102.

30. Shelley WB, Melton FM. Factors accelerating the penetration of histamine through normal intact skin. J Invest Dermatol. 1949;13: 61-72.

31. Fridovich I. Superoxide dismutases. Adv Enzymol. 1986;58: 61-97.

32. Sorenson JRJ. Copper complexes offer a physiological approach to treatment of chronic diseases. Progr Med Chem. 1989;26: 437-568.

33. Sorenson JRJ. Some copper chelates and their antiinflammatory and antiulcer activities. Inflammation. 1976;1:317-22.

34. Jackson GE, May PM, Williams DR. Metal-ligand complexes involved in rheumatoid arthritis. J Inorg Nucl Chem. 1978;40: 1189-94.

35. May PM, Linder PW, Williams DR. Computer simulation of metal-ion equilibria in biofluids: models for the low-molecularweight complex $\mathrm{d}$ istribution of calcium(II), magnesium(II), manganese(II), iron(III), copper(II), zinc(II), and lead(II) ions in human blood plasma. J Chem Soc Dalton Trans. 1977;6: 588-95.

36. Furnival C, May PM, Williams DR. Models of low-molecularweight copper(II) complexing equilibria in relation to rheumatoid arthritis. In: Rainsford KD, Brune K, Whitehouse MW, editors. Trace elements in the pathogenesis and treatment of inflammation. Basel: Birkhäuser Verlag; 1981. p. 241-57.

37. Cousins RJ. Absorption, transport, and hepatic metabolism of copper and zinc: special reference to metallothionein and ceruloplasmin. Physiol Rev. 1985;65:238-309.

38. Powanda MC. Systemic alterations in metal metabolism during inflammation as part of an integrated response to inflammation. Agents Actions 1981; Suppl 8:121-135.

39. Iyengar GV, Kollmer WE, Bowen HJM. The elemental composition of human tissues and body fluids. New York: Verlag Chemie; 1978.

40. Milanino R, Frigo A, Bamabara LM, Marrella M, Moretti U, Pasqualicchio M. Copper and zinc status in rheumatoid arthritis: studies on plasma, erythrocytes and urine, and relationship with disease activity markers and pharmacological treatment. Clin Exp Rheumatol. 1993;11:271-81.

41. Milanino R. Copper in medicine and personal care: a historical overview. In: Hostynek JJ, Maibach HI, editors. Copper and the skin. New York: Informa Healthcare; 2006. p. 149-60. 
42. Harrison BJ. Copper jewelry and arthritis. In: Hostynek JJ, Maibach HI, editors. Copper and the skin. New York: Informa Healthcare; 2006. p. 237-66.

43. Fairlie DP, Whitehouse MW. Transdermal delivery of inorganic complexes as metal drugs or nutritional supplements. Drug Des Discov. 1991;8:83-102.

44. Chernomorsky SA, Segelman AB. Biological activities of chlorophyll derivatives. New Jersey Med. 1988;85:669-73.

45. DHSS. Deodorant over-the-counter drug products for internal human use CFR 21, part 357. Fed Reg. 1985;50:25162-7.
46. Gorter RW, Butorac M, Cobian EP. Examination of the cutaneous absorption of copper after the use of copper-containing ointments. Am J Ther. 2004;11:453-8.

47. Potts RO, Guy RH. Predicting skin permeability. Pharm Res. 1992;9:663-70.

48. Levin J, Maibach HI. Human skin buffering capacity: an overview. In: Zhai $\mathrm{H}$, Wilhelm K-P, Maibach HI, editors. Dermatotoxicology. 7th ed. Boca Raton: CRC Press; 2000. p. $971-80$. 